\title{
Reaction of some weed species to herbicides in sugar beet cultivation
}

\author{
H. DOMAŃSKA, L. LESKA, Z. LĘGOWIAK, G. MAĆKOWIAK
}

Institute of Plant Production, Warsaw Agricultural University - SGGW-AR, ul. Rakowiecka 26/30,

02-528 Warszawa, Poland

\begin{abstract}
In the years 1975-1980, on the Experimental Farm Chylice fields of the Warsaw Agricultural University, herbicide activity was evaluated on commonly appearing weed species in sugar beet cultivation. The most frequent weeds were: Chenopodium album, Echinochloa crus-galli, Polygonum convolvulus and Polygonum lapatifolium. Preemergence use of chloridazon and furthermore postemergence use of phenmedipham were most effective in control. Metolachlor or bentiocarb mixed with metamitron and chloridazon were effective too. It was found that $70 \%$ control of Chenopodium album increased crops of sugar beets by about $25 \%$ on the basis of two years experiments (1979-1980), differing in quantity and periods of rainfall, a visible dependence of herbicide effectiveness on climatic conditions was demonstrated.
\end{abstract}

\section{INTRODUCTION}

The effect of most herbicides is highly variable in dependence on the climatic conditions in the period of their application. The soil moisture and temperature condition not only the phytotoxic of herbicides applied into the soil, but also of others used as top dressing after plant emergence as for instance diclofopmethyl ester the phytotoxic action of which is reduced by 50 per cent when soil moisture is low.

Investigations conducted in Davis (California) under field and controlled conditions demonstrated that a high soil moisture level (ca $67 \% \mathrm{FWC}$ ) lasting for 2-4 days after spraying the beets with this herbicide ensured very good efficiency of this treatment ( $\mathrm{D}$ or te $\mathrm{n} \mathrm{zi}$ o and $\mathrm{N}$ or r i s, 1980). No changes were noted in the rate and extent of absorption and translocation of diclofopmethyl labelled with ${ }^{14} \mathrm{C}$ in several weed species (Echinochloa crus-galli, Setaria lutescens, Avena fatua and Phalaris minor) at various soil moisture levels. It would seem that the phytocidal action of the herbicide is rather dependent on the germination date of the seeds immediately after its application.

Similar observations on the influence of soil moisture on the effectiveness of ethofumesate were reported by $\mathrm{M}$ a y $\mathrm{k} \mathrm{h}$ u s (1979). 
In nearly all investigations on the activity of herbicides and their tolerance by the sugar beet more and more attention is devoted to their ability of destroying Echinochloa crus-galli. As a later germinating weed it is not affected by preemergent and post-seeding treatment with herbicides and it is a serious threat to beets, particularly when spring is cold.

Echinochloa, a thermophilous species appears only when the temperature reaches $10-15^{\circ} \mathrm{C}$. It is also hygrophilous and its mass germination is conditioned, beside temperature, by soil moisture. An optimal state of both these factors favours germination of the caryopsis which only then can be affected by the phytotoxic action of the herbicide. Accumulation of Echinochloa crus-galli caryopsis in the soil occurs especially when symazin and atrazin, to which this species has become resistant, are applied in maize ( $M$ a y k h u s, 1979). Farm manure from animals fed silaged maize containing E. crus-galli caryopsis resistant to gastric juices also increases infestation of crops by this species. It results from the observations of $\mathrm{Ma} \mathrm{y} \mathrm{k} \mathrm{h} \mathrm{u} \mathrm{s}$ in the region of Hannover (West Germany) that mechanical management practices between the rows stimulate germination of new batches of Echinochloa caryopsis and phenmedipham is noxious to this weed up to the 2-leaf phase like ethofumesate. Both these herbicides applied consecutively at an interval of about one week destroy. E. crusgalli in the 2-4-leaf phase. The period of phytotoxic action on this species of alloxydim sodium and diclofopmethyl is somewhat longer, destroying E. crusgalli up to the 6-leaf phase. According to the above named author such a mixture can be used up to the moment of shooting of the weed without injury to the beets (M a y k h u s, 1979).

When mixtures of herbicides were used certain interrelations were noticed in their phytotoxic action in dependence on the composition of the mixture, and namely, synergism and antagonism between some substances. An effect of synergic action on E. crus-galli was observed when cycloate was applied before seeding and phenmedipham after emergence. The effectiveness of phenmedipham increased considerably as compared with that under conditions where cycloate was not used. Studies of four years duration in Canada (D a w s o $n, 1975$ ) in search for the most economic and safest for beets mode of phenmedipham application demonstrated that after pre-emergent spraying of the field with cycloate $(3.4 \mathrm{~kg} / \mathrm{ha})$ phenmedipham $(1.1 \mathrm{~kg} / \mathrm{ha})$ destroyed Chenopodium album in 90-100 per cent, whereas without the pre-emergent treatment with cycloate this plant was completely resistant to phenmedipham. Unfortunately the beets were also injured by this herbicide combination, whereas phenmedipham, even in double dose, did not produce any phytotoxic symptoms in the beets.

The dependence of the beet yield on the species composition and bulk of the weed is beyond discussion. The reaction of the crop plant, however, to the dominance of the particular weed species varies in their group. S c h w e r dt 1 e (1975) reports results of field experiments which confirm the influence of 
weed contamination on beet yield. In these investigations Chenopodium album or Galium aparine dominated in the weed composition. Where $C h$. album was dominant (48-69\% of all weeds) the root and leaf crop varied within $0.75-4$ tons/ha, whereas on areas where Galium aparine prevailed $(46-64 \%$ in total amount of weeds) the beet crop varied within the limits of 15-28 tons/ha. Thus, the species belonging to the same botanical family (Chenopodiaceae) as the beet is a more dangerous competitor and when $C h$. album reached a proportion as low as 6-26 per cent in the total weed mass, the beet yield was as low as 13.7-28 tons/ha.

$\mathrm{M}$ a y k h u s (1979) found that E. crus-galli appearing in the number of 40100 plants on $1 \mathrm{~m}^{2}$ depressed the beet crop by 28 per cent and made the harvest difficult.

The failure in the expected effects of herbicide application was frequently noted under conditions unfavourable for action of the active substance making weed germination impossible in the course of the two weeks following application of the herbicides. S $\mathrm{c} \mathrm{h}$ a u f e l e and W i n t e $\mathrm{r}$ (1979) suggest the necessity of using herbicides at three dates. The present results confirm these observations. The herbicides were applied at only two dates, but their effectiveness was highest in this treatment, even if they were not graminicides but chloridazon and phenmedipham.

Comparison of the effect obtained in two successive years 1979 and 1980 differing widely as regards meteorological conditions points to the decisive role of weather factors which may completely abolish the effectiveness of substances highly active under conditions of another vegetation period.

\section{METHODS}

The experiments were performed in the years 1976-1980 in the Experimental Agricultural Station of the Warsaw Agricultural University at Chylice. Sugar beets of the 'AJ Polycama' variety were seeded on black soil from light and medium boulder clay (bonitation class III). The soil parameters were as follows: organic matter content 1.1-1.7 per cent, phosphorus and potassium evaluated by the method of Egner (7.1-9.0 $\mathrm{mg}_{2} \mathrm{O}_{5}$ and 6.0-6.9 $\mathrm{mg} \mathrm{K}_{2} \mathrm{O}$ in $100 \mathrm{~g}$ of soil, $\mathrm{pH}$ 6.0-7.0.

The experiments were organized by the random blocks method in four replications. The plot surface area was $30-40 \mathrm{~m}^{2}$. The herbicides were applied at two dates:

1) immediately after seeding (single preparations and mixtures),

2) after emergence at 2-4-leaf phase of beets -- phenmedipham and diclofopmethyl.

The effectiveness of the herbicides was evaluated from the fresh mass of weeds collected from a $1 \mathrm{~m}^{2}$ surface according to species. Weed contamination was evaluated at two dates: 
1) 7-10 days after pre-emergent spraying,

2) 30 days before the beet harvest.

The reaction of the crop plant was evaluated according to the number of germinating seeds, the root and leaf crop, the sugar content and ash components in the roots.

Data here presented are part of the results obtained in five-year field experiments performed partly under a grant from the Institute of Plant Breeding and Acclimatization.

\section{RESULTS}

Weed contamination of the beet fields in the years of the experiment varied as regards mass, species composition and proportions between species. Chenopodium album was dominant constituting about 60 per cent of the total weed mass (Table 1). Echinochloa crus-galli was much more abundant, as indicated by the number of seedlings collected on $1 \mathrm{~m}^{2}$, although at the time of sampling its mass did not equal that of Chenopodium album (e.g. in 1980 E. cruss-galli 196 seedlings were collected and 115 of Ch. album). E. crus-galli germinates much later and at the time of collection was much less advanced in growth than the early germinating Ch. album. Polygonum convolvulus and $P$. lapatifolium came next in abundance constituting about 8 per cent of the total mass of weeds. Proportions between the weeds varied in the years of the experiment (Table 2).

Beside the above listed four species the following weeds were present: Viola arvensis, Lamium amplexicaule, Stellaria media, Veronica sp., Euphorbia helioscopia, Anagalis arvensis, Sinapis arvensis, Raphanus raphanistrum, Linaria minor, Galium aparine, Solanum nigrum, Tripleurospermum inodorum, Anthemis arvensis, Papaver rhoeas, Fumaria officinalis (Table 1). They constituted jointly about 16 per cent of the total weed mass.

The effectiveness of the herbicides 〈Table 3 > evaluated in terms of weed destruction expressed as percentage of control varied within the range 35.0-88.6 per cent. Post-seeding application of chloridazon together with post-emergence phenmedipham treatment proved most effective ( $88.6 \%$ destruction of all weeds). Somewhat less satisfactory in relation to all weeds were the mixtures used after seeding composed of chloridazon with other herbicides (e.g. Pyramin + Merpelan AZ, Pyramin + Saturn 50 EC) as well as metamitron with benthiocarb and metolachlor and metamitron alone. Mixtures containing ethofumesate were not sufficiently efficient. Dual $720 \mathrm{EC}$, as graminicide could not be very useful against all weeds, among which Chenopodium album dominated. Most of the herbicides applied, with the exception of Northron and mixtures containing the latter, destroyed efficiently $\mathrm{Ch}$. album. The highest percentage of destruction of this species was achieved by applying Pyramin and Betanal, it was also high when Goltix, Goltix + Saturn, Pyramin + Merpelan AZ, Goltix + Dual 720 EC, Merpelan AZ were used. 
Table 1

Effectiveness of herbicides. Average for the years 1976-1980

\begin{tabular}{|c|c|c|c|c|c|c|c|c|}
\hline \multirow[b]{2}{*}{ Herbicides } & \multirow{2}{*}{$\begin{array}{c}\text { Dose } \\
\mathrm{kg} \times \mathrm{ha}^{-1} \\
\mathrm{l} \times \mathrm{ha}^{-1}\end{array}$} & \multicolumn{7}{|c|}{ Weed control in percentage } \\
\hline & & $\begin{array}{c}\text { fresh } \\
\text { weight of } \\
\text { total weeds }\end{array}$ & $\begin{array}{l}\text { Chenopodium } \\
\text { album }\end{array}$ & $\begin{array}{l}\text { Viola } \\
\text { arvensis }\end{array}$ & $\begin{array}{l}\text { Polygonum } \\
\text { convolvulus }\end{array}$ & $\begin{array}{l}\text { Polygonum } \\
\text { lapatifolium }\end{array}$ & $\begin{array}{l}\text { Echinochloa } \\
\text { crus-galli }\end{array}$ & $\begin{array}{l}\text { other } \\
\text { species }\end{array}$ \\
\hline Pyramin+Betanal & $4+6$ & 88.6 & 97.6 & 86.3 & 99.1 & 94.9 & 2.0 & 91.7 \\
\hline Pyramin+Dual 720 EC & $3+2$ & 60.4 & 59.5 & 65.8 & 37.6 & 58.7 & 63.7 & 74.6 \\
\hline Pyramin+Saturn 50 EC & $3+8$ & 61.0 & 61.6 & 37.0 & 65.1 & 80.6 & 3.5 & 82.7 \\
\hline * Pyramin+Marpelan AZ & $3+3$ & 72.7 & 82.4 & 21.3 & 90.9 & 90.3 & 0 & 66.9 \\
\hline Pyramin+Northron & $3+5$ & 47.2 & 39.5 & $\mathbf{0}$ & 93.1 & 74,3 & 5.1 & 76.7 \\
\hline Northron+Venzar & $5+0.75$ & 35.0 & 30.9 & 16.4 & 56.4 & 22.2 & 38.6 & 44.8 \\
\hline Northron+Illoxan 36 EC & $5+3$ & 42.1 & 31.1 & 12.3 & 0 & 65.4 & 96.9 & 74.2 \\
\hline Northron & 7.5 & 38.6 & 36.8 & 0 & 44.1 & 57.2 & 0 & 69.7 \\
\hline${ }^{*}$ Goltix+Dual 720 EC & $5+2$ & 67.1 & 75.3 & 50.0 & 66.6 & 53.3 & 67.5 & 45.6 \\
\hline${ }^{*}$ Goltix+Saturn 50 EC & $5+8$ & 72.3 & 86.9 & 32.0 & 60.7 & 92.2 & $\mathbf{3 5 . 3}$ & 67.0 \\
\hline${ }^{*}$ Goltix & 8 & 66.7 & 87.2 & 75.0 & 91.2 & 83.0 & $\mathbf{0}$ & 59.9 \\
\hline Merpelan AZ & 4 & 60.9 & 70.0 & 47.2 & 77.3 & 78.5 & $\mathbf{0}$ & 72.9 \\
\hline Dual 720 EC & 3 & 44.7 & 63.5 & 0 & 9.0 & $\mathbf{0}$ & 80.2 & 66.9 \\
\hline 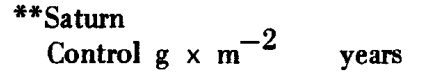 & 10 & 41.7 & 52.6 & $\mathbf{0}$ & 64.7 & 0 & 10.2 & 52.0 \\
\hline * $1976-1979$ & & 479.8 & 285.3 & 8.0 & 30.9 & 39.3 & 29.4 & 86.9 \\
\hline $1976-1980$ & & 479.8 & 284.1 & 7.2 & 37.4 & 33.0 & 36.3 & 81.8 \\
\hline $1977-1980$ & & 543.8 & 333.0 & 7.3 & 44.7 & 31.5 & 45.4 & 81.9 \\
\hline
\end{tabular}

${ }^{*}$ means for 5 years, **means for 4 years. 
Ta b le 2

Comparison of herbicide effectives in 1979 and 1980

\begin{tabular}{|c|c|c|c|c|c|c|c|c|c|}
\hline \multirow{4}{*}{ Herbicides } & \multirow{4}{*}{$\begin{array}{c}\text { Dose } \\
\mathrm{kg} \times \mathrm{ha}^{-1} \\
\mathbf{l} \times \mathrm{ha}^{-1}\end{array}$} & \multicolumn{8}{|c|}{ Weed control in percentage } \\
\hline & & \multirow{2}{*}{\multicolumn{2}{|c|}{$\begin{array}{c}\text { Chenopodium } \\
\text { album }\end{array}$}} & \multirow{2}{*}{\multicolumn{2}{|c|}{$\begin{array}{l}\text { Echinochloa } \\
\text { crus-galli }\end{array}$}} & \multicolumn{4}{|c|}{ Polygonum } \\
\hline & & & & & & \multicolumn{2}{|c|}{ convolvulus } & \multicolumn{2}{|c|}{ lapatifolium } \\
\hline & & 1979 & 1980 & 1979 & 1980 & 1979 & 1980 & 1979 & 1980 \\
\hline Pyramin+Betanal & $4+6$ & 96.8 & 100.0 & 0 & 95.9 & 87.7 & 100.0 & 95.6 & 100.0 \\
\hline Pyramin+Dual $720 \mathrm{EC}$ & $3+2$ & 52.3 & 85.2 & 14.0 & 74.5 & 1.5 & 87.5 & 57.0 & 68.7 \\
\hline Pyramin+Satum 50 EC & $3+8$ & 21.4 & 90.8 & 0 & 92.2 & 83.1 & 98.4 & 88.8 & 100.0 \\
\hline Pyramin+Marpelan AZ & $3+3$ & 79.7 & - & 0 & - & 38.5 & - & 92.1 & - \\
\hline Pyramin+ Northron & $3+5$ & 0 & 100.0 & 0 & 86.1 & 75.4 & 99.8 & 89.6 & 100.0 \\
\hline Northron+Venzar & $5+0.75$ & 0 & 61.5 & 0 & 62.5 & 0 & 86.8 & 17.9 & 98.0 \\
\hline Northron+Illoxan $36 \mathrm{EC}$ & $5+3$ & 0 & 68.2 & 99.3 & 100.0 & 0 & 0 & 66.4 & 84.4 \\
\hline Northron & 7.5 & 0 & 73.3 & 0 & 2.0 & 0 & 65.7 & 71.6 & 51.6 \\
\hline Goltix $720 \mathrm{EC}$ & $5+2$ & 64.1 & 99.8 & 26.2 & 93.6 & 0 & 97.6 & 91.2 & 100.0 \\
\hline Goltix+Saturn 50 EC & $5+8$ & 77.8 & 99.8 & 0 & 84.0 & 0 & 98.6 & 89.8 & 100.0 \\
\hline Goltix & 8 & 88.5 & 99.9 & 0 & 0 & 55.4 & 98.0 & 89.4 & 100.0 \\
\hline Merpelan AZ & 4 & 51.3 & 97.8 & 0 & 66.0 & 26.2 & 99.0 & 88.4 & 92.2 \\
\hline Dual $720 \mathrm{EC}$ & 3 & 29.7 & 48.5 & 66.3 & 99.6 & 0 & 38.7 & 0 & 34.3 \\
\hline Saturn 50 EC & 10 & 7.1 & - & 0 & $\ldots$ & 67.7 & - & 0 & - \\
\hline Control $\mathrm{g} \times \mathrm{m}^{-2}$ & & 424.8 & 279.5 & 73.8 & 64.0 & 6.5 & 63.2 & 85.8 & 8.0 \\
\hline
\end{tabular}

Date of application: 27.04 and $25.05 .1979 ; 8.05$ and 7.06.1980.

Date of weed determination: 1.06. 1979; 16.06. 1980. 
Table 3

Characteristic of herbicides

\begin{tabular}{lll}
\hline $\begin{array}{c}\text { Proprietary } \\
\text { name }\end{array}$ & \multicolumn{1}{c}{$\begin{array}{c}\text { Current name of active } \\
\text { substance }\end{array}$} & $\begin{array}{c}\text { Active substance } \\
\text { content }\end{array}$ \\
\hline Betanal & phenmediapham & 16.5 \\
Goltix & metamitron & 70.0 \\
Illoxan & diclofopmethyl & 36.0 \\
Dual 720 EC & metolachlor & 72.0 \\
Merpelan A7. & izokarbamid+lenacil & 78.0 \\
Northron & ethofumesate & 20.0 \\
Pyramin & chloridazon & $\mathbf{8 0 . 0}$ \\
Saturn 50 EC & benthiocarb & $\mathbf{5 0 . 0}$ \\
Venzar & lenacil & $\mathbf{8 0 . 0}$ \\
\hline
\end{tabular}

The best effect $(96.9 \%)$ in the control of Echinochloa crus-galli was obtained with the mixture of ethofumesate with diclofopmethyl. Results were also positive $(63.7-80.2 \%)$ with metolachlor alone and in mixtures with other substances. The mixture Pyramin + Dual 720 EC affected much less E. crus-galli, only in 63.7 per cent, similarly as did the mixture Goltix + Dual $720 \mathrm{EC}(67.5 \%)$. The remaining combinations of herbicides were but little useful in control of this species.

Polygonum convolvulus was best controlled by the following herbicides: Pyramin after seeding + Betanal used after emergence $(99.1 \%)$. Highly efficient against this species were the following mixtures: Pyramin + Nortron and Goltix alone. The weed did not react, however, to Nortron + Illoxan $36 \mathrm{EC}$ nor to Dual $720 \mathrm{EC}$ alone (Table 1). $P$. lapatifolium is more susceptible under conditions of sparse precipitation, although it proved resistant to metolachlor and benthiocarb.

Post-seeding application of chloridazon and after emergence of phenmedipham was most effective in control of Viola arvensis. This species is not susceptible to most of the herbicides used in the experiment. It results from the data in Table 2 that this weed is rather well controlled by metamitron, but addition of metolachlor or benthiocarb reduces its effect on $V$. arvensis.

The remaining species were satisfactorily controlled by nearly all herbicide combinations.

The action of herbicides on the some weed species varied markedly in the particular years. It was evaluated in two widely differing vegetation periods. The effects were compared in 1979 and 1980 and only in reference to the four most abundant weed species (Table 2). A markedly more efficient activity of herbicides was noted in 1980. Northron and mixtures containing it, inefficient towards Chenopodium album in 1979 destroyed this species in 61.5-100 per cent in 1980.

Similarly Echinochloa crus-galli was controlled in 1979 only by highly active graminicides such as Illoxan $36 \mathrm{EC}$ and Dual $720 \mathrm{EC}$. The efficiency of the latter 
in mixtures in 1979 was lower than that of the preparation alone. In 1980, however, destruction of E. crus-galli varied within 65.2-100 per cent. Goltix and Northron were inefficacious in both years against this species.

A weed difficult to control is Polygonum convolvulus. Ethofumesate and its mixtures, the combination with Pyramin excepted, proved inefficient against this species. The susceptibility of both species of the genus Polygonum to various substances varies widely.

Combinations of herbicides such as Northron + Illoxan 36 EC, Pyramin + Dual $720 \mathrm{EC}$, finally Northron alone are not useful against $P$. convolvulus, but they satisfactorily reduced the mass of $P$. lapatifolium (Table 2). Benthiocarb (prep. Saturn $50 \mathrm{EC}$ ) which but little efficient in the control of E. crus-galli and $P$. lapatifolium was toxic to $P$. convolvulus.

Ta b l e 4

Rainfall distribution in the period from sowing of sugar beet to determination of weeds

\begin{tabular}{|c|c|c|c|c|c|c|c|c|}
\hline & \multicolumn{8}{|c|}{ Rainfall in $\mathrm{mm}$} \\
\hline & \multicolumn{5}{|c|}{1979} & \multicolumn{3}{|c|}{1980} \\
\hline Month & Ten-day & periods & Days of & month & $\Sigma$ & $\begin{array}{c}\text { Ten-day } \\
\text { periods }\end{array}$ & Days of month & $\Sigma$ \\
\hline April & $\begin{array}{r}\text { I } \\
\text { II } \\
\text { III }\end{array}$ & $\begin{array}{r}12.0 \\
4.1 \\
8.8\end{array}$ & $\left.\begin{array}{l}27.04-0.0 \\
28.04-0.0 \\
29.04-0.8 \\
30.04-4.3\end{array}\right)$ & & 24.9 & $\begin{array}{r}13.0 \\
5.0 \\
36.0\end{array}$ & & $\mathbf{5 4 . 0}$ \\
\hline May & $\underset{\text { III }}{\text { I }}$ & $\begin{array}{r}21.4 \\
1.4 \\
6.6\end{array}$ & & 34.5 & 29.4 & $\begin{array}{r}0.3 \\
\\
0.4 \\
17.0\end{array}$ & $\left.\begin{array}{r}8.05-0.0 \\
9.05-0.3 \\
10.05 .-0.0\end{array}\right)$ & 21.3 \\
\hline \multirow[t]{2}{*}{ June } & $\begin{array}{r}\text { I } \\
\text { II }\end{array}$ & $\begin{array}{r}0.7 \\
18.2\end{array}$ & & & $\mathbf{5 3 . 4}$ & $\begin{array}{l}61.0 \\
75.0\end{array}$ & $\left.\begin{array}{l}11.06 .-13.7 \\
12.06 .-25.7 \\
13.06 .-0.0 \\
14.06 .-0.0 \\
15.06 .-19.0\end{array}\right\}$ & 162.0 \\
\hline & III & 34.5 & & & 26.0 & & & \\
\hline
\end{tabular}

Sowing date of sugar beet: $26.04 .1979 ; 5.05 .1980$.

Date of herbicides application: 27.04.1979; 8.05.1980.

Date of weed determination: $1.06 .1979 ; 16.06 .1980$. 
The difference in the action of herbicides in the particular years is mainly dependent on climatic factors. The low efficiency in 1979 as compared with 1980 may be explained by the small amount of precipitation in the period before and after application of the herbicides. In April 1979 the sum of precipitation was 24.9, and in 1980 it was $54.0 \mathrm{~mm}$ (Table 4). In the period from post-seeding application of the herbicides to the time of evaluation of weed contamination, precipitation in 1979 amounted to $34.5 \mathrm{~mm}$ and in 1980 it exceeded this amount by $106.2 \mathrm{~mm}$. Under conditions of drought (Table 4) and higher temperature in 1979 the solubility of some substances was poorer and the lack of phytotoxicity to weeds understandable.

Elimination of weeds at a possibly early date by appropriate management practices ensures higher yields. The results of experiments performed in 19761980 (Fig. 1) indicate that weed control within the range of 35.0-88.6 per cent contributed to an increase in the sugar beet root crop.

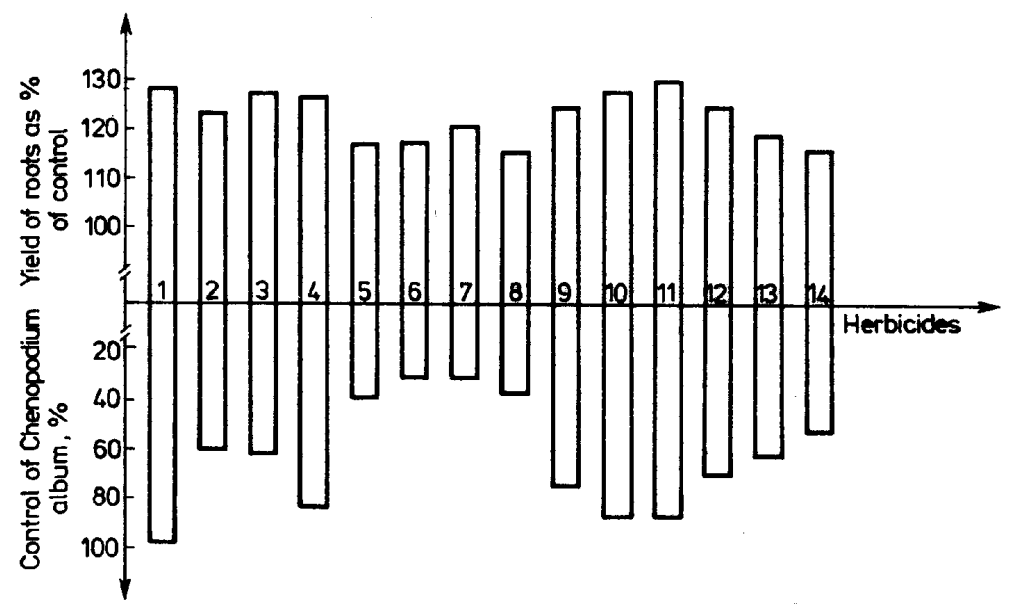

Fig. 1. Influence of herbicides on Chenopodium album and yields of sugar beet roots. Average for the years 1976-1980

1- Pyramin + Betanal, 2 - Pyramin + Dual 720 EC, 3 - Pyramin + Saturn 50 EC, 4 - Pyramin

+ Merpelan AZ, 5 - Pyramin + Northron, 6 - Northron + Venzar, 7 - Northron + Illoxan 36 EC, 8 - Northron, 9 - Goltix + Dual 720 EC, 10 - Goltix + Saturn 50 EC, 11 - Goltix, 12 Merpelan AZ, 13 - Dual 720 EC, 14 - Saturn 50 EC

\section{CONCLUSIONS}

1. Most reliable proved to be for all weeds over the five-year period of testing the combination of chloridazon after seeding with phenmedipham after emergence of the beets (Table 1). 
2. Under conditions of the dry and warm spring of 1979 which favoured germination of thermophilous species the mixture of ethofumesate with diclofopmethyl destroyed Echinochloa crus-galli in 99.3 per cent and metolachlor in 66.3 per cent. In the wet spring of 1980 the action of these preparations was still more efficient (100 and $99.6 \%$ of destruction, Table 2 ).

3. The phytotoxic action on Chenopodium album of metolachlor and its mixture with chloridazon and metamitron, chloridazon with benthiocarb and izocarbamid + lenacyl (prep. Merpelan AZ) differed widely in the two compared vegetation seasons (Table 2).

4. Polygonum convolvulus in the dry spring of 1979 was resistant to most of the preparations applied, whereas in 1980 only the mixture of Northron + Illoxan was completely ineffective and Dual $720 \mathrm{ED}$ affected the weeds but weakly $(38.7 \%$ destruction).

5. In the year 1979 unfavourable to the action of herbicides Polygonum lapatifolium was much more sensitive to most of the applied substances in the beet crop than Polygonum convolvulus.

6. Chenopodium album is the weed species which competes most dangerously with the sugar beet. When it was destroyed in 70 per cent, the root crop increased by about 25 per cent.

\section{REFERENCES}

D a w s o n J. H., 1975. Cycloate and phenmedipham as complementary treatments in sugar beets. Weed Science 23: 478-485.

D o r t e n z i o W. A., N o r $r$ is R.F., 1980. The influence of soil moisture on the foliar activity of diclofop. Weed Science 28: 534-539.

M a y k h u s F., 1979. L' infestation et la lutte contre les millets dans les betteraves a sucre et les pommes de terre. Gesunde Pflantzen. 31: 113-116. cyt. Bull. d' Inf. Inst. Belge pour l' Amelior. de la Betterave - Tienen, 1979. 14, 7.

$\mathrm{S} c$ h a $u$ f e l e W. R., W i n t e r C., 1979. Des essais en champ avec l' herbicide Goltix en culture de betteraves a' sucre. Cyt. Bull. d' Inform. Inst. Belge pour l' Amelior. de la Betterave - Tienen, 1979. 14, 7: 53-54.

$\mathrm{Sch}$ e r d t le F., 1975. La signification de quelques especes de plants adventices pour le rendement des betteraves. Zeitsch. Pfl. Krankheiten und Pfl. Schutz Sonderh. VII. 57-62. Cyt. Bull. d' Inform. Inst. Belge pour l' Amelioration de la Betterave - Tienen. 1977. XII, 1: 38-39.

\section{REAKCJA NIEKTÓRYCH GATUNKÓW CHWASTÓW NA HERBICYDY STOSOWANE W PIELĘGNACJI BURAKÓW CUKROW.YCH}

$$
\text { Streszczenie }
$$

W latach 1975-80 przeprowadzone w RZD Chylice SGGW-AR doświadczenia dotyczące reakcji niektórych gatunków chwastów na herbicydy stosowane w pielęgnacji buraków cukrowych. Dominującymi gatunkami byly: Chenopodium album, Echinochloa crus-galli, Polygonum convolvulus, 
Polygonum lapatifolium. Zastosowanie chlorydazonu po siewie buraków cukrowych + fenmedifam po wschodach wykazało najwyższy efekt chwastobójczy. Metolachlor lub bentiokarb w mieszankach $\mathrm{z}$ metamitronem i z chlorydazonem były również skuteczne. Zniszczenie Chenopodium album w $70 \%$ przyczynilo się do wzrostu plonów o około $25 \%$.

Na przykładzie dwu kolejnych lat o zróżnicowanych ilościach i rozkładzie opadów $\langle 1979$ i 1980 $\rangle$ wykazano zależność skuteczności herbicydów od przebiegu warunków klimatycznych. 